\title{
Lead Concentrations and Risk Exposure Assessment in Surface Soils at Residential Lands Previously Used for Auto-Mechanic and Auto-Welding Activities in Port Harcourt, Nigeria
}

\section{$*^{1}$ NDOKIARI, BOISA; ${ }^{1}$ ERIC, JULIET OLOH}

\author{
${ }^{I}$ Department of Chemistry, Faculty of Science, \\ Rivers State University, Port Harcourt, Nigeria \\ Corresponding author's email: boisa.ndokiari@ust.edu.ng
}

\begin{abstract}
This study investigated lead concentrations in $<250 \mu \mathrm{m}$ and $<75 \mu \mathrm{m}$ of deposited dust and $<2000$ $\mu \mathrm{m},<250 \mu \mathrm{m}$, and $<75 \mu \mathrm{m}$ of surface soils at undeveloped residential lands leased to auto-mechanic artisans for a minimum of ten years and estimated exposure risk for children that will reside on the polluted lands after the lease periods. Soil- $\mathrm{Pb}$ levels ranges obtained were between $40.0-411 \mathrm{mg} / \mathrm{kg}, 62.0-435 \mathrm{mg} / \mathrm{kg}$, and $61.0-491 \mathrm{mg} / \mathrm{kg}$ for $<$ $2000 \mu \mathrm{m},<250 \mu \mathrm{m}$ and $<75 \mu \mathrm{m}$ fractions, respectively. Dust-Pb levels ranges were between $138-1819 \mathrm{mg} / \mathrm{kg}$, and $128-1584 \mathrm{mg} / \mathrm{kg}$ for $<250 \mu \mathrm{m}$ and $<75 \mu \mathrm{m}$ fractions, respectively. The estimated daily intake were in the range of $0.17-1.22 \mu \mathrm{g} \mathrm{Pb} \mathrm{Kg}^{-1}$ body weight $[\mathrm{BW}] \mathrm{d}^{-1}$ and $0.39-5.11 \mu \mathrm{g} \mathrm{Pb} \mathrm{Kg}^{-1} \mathrm{BWd}^{-1}$ for soil and deposited dust, respectively. This study has highlighted possible risks to occupants of lands previously used for auto-mechanic and auto-welding activities. (C) JASEM
\end{abstract}

https://dx.doi.org/10.4314/jasem.v21i5.2

Keywords: Lead, Exposure, Children, Auto-mechanic, Auto-welding, soil

Lead is included in the formulation of several motor oils. Leaded gasoline has been phased out, but is still used in parts of Africa (Tuakuila et al., 2010). Automechanic yards may still be point sources of lead pollution because unacceptable lead concentrations in the range of $1500-9300 \mathrm{mg} / \mathrm{kg}$ have been reported for gear and motor oils by Clausen and Rastogi, (1977). The legacy of the auto-mechanic activities is usually not investigated and remediated; consequently people that develop their residential homes at sites previously used for auto-mechanic services may be exposed to surface soil-lead through the inhalation of re-suspended dust and ingestion of garden food (e.g. Boisa et al., 2013; Laidlaw et al 2014; Mackay et al 2013; Zahran et al., 2013; Boisa et al., 2014). Exposure could also occur via borehole ground water, since Government treated pipe borne water is hardly available in cities of most developing countries including Nigeria.

Human exposure to motor garage chemicals has been suggested to induce genotoxic effects (Oktem et al., 2004; Shastri and Plant, 2011; ; Eum et al 2013; Pottier et al., 2013; Weuve et al., 2013; Hong et al., 2015). Results of previous epidemiological studies conducted on adolescent workers indicated elevated blood lead levels for auto- mechanics and garage owners (Enander et al., 2004; Oktem et al., 2004; Tuakuila et al., 2010; Adela et al., 2012). Previous published studies (e.g. Adelekan and Abegunde, 2011) at mechanic garages in Nigeria investigated contaminant levels without considering exposure risk to the artisans on site or risk to population that may reside permanently at the emerging Brownfield areas. The aim of this study is to investigate lead concentrations in surface soils at residential lands leased to auto-mechanic and auto-welding artisans and estimate exposure risk to both artisans and people who will reside permanently on such lands.

\section{MATERIAL AND METHODS}

Study sites: Port Harcourt has large number of automechanic service stations that are situated at private lands and roadsides. The study was conducted at selected roadsides (RS) and residential yards (YD) used as auto-mobile mechanic service stations within Port Harcourt City, Nigeria.

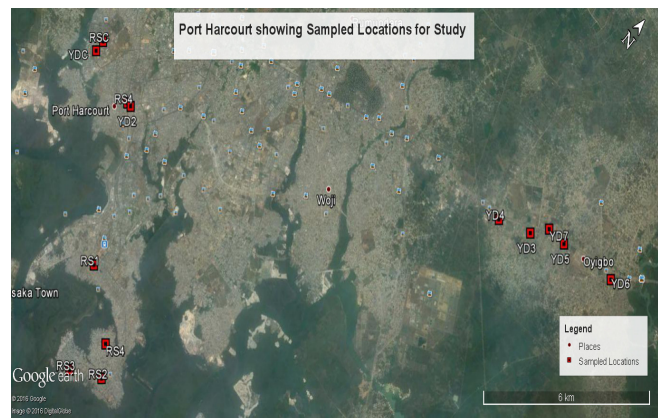

Fig 1: Map showing different sample sites

The criteria employed for the qualification of any of the sites was proximity to nursery and primary schools. Other factors considered were closeness to roadside commercial barbeque snacks points (e.g. for roasted plantain), children playgrounds and uncontaminated land (C). The zones of Port Harcourt 
captured in this study were Town (RS1), Borokiri (RS2, RS3 and YD1), Ikoku (YD2 and RS4), Rivers State University -RSU (RSC and YDC) and Oyibo (YD3, YD4, YD5, YD6 and YD7) (Figure 1). Details about the type of auto-mechanic services provided, public institutions and nature of surfaces at each of the study sites are listed in Table 1.

Table 1: Study sites and sampling details

\begin{tabular}{lllll}
\hline Sample Code & $\begin{array}{l}\text { Description of } \\
\text { sample point }\end{array}$ & $\begin{array}{l}\text { Port Harcourt } \\
\text { Zone }\end{array}$ & Mech. activity & Vegetation \\
\hline RS1 & Roadside & Town & Car engine service & Exposed topsoil \\
RS2 & Roadside & Borokiri & Car engine service and body refinishing & Exposed topsoil \\
RS3 & Roadside & Borokiri & Car engine service & Exposed topsoil \\
YD1 & Fenced Yard & Borokiri & Metal scrap dump & Exposed topsoil \\
YD2 & Fenced Yard & Ikoku, Diobu & Car engine service and body refinishing & Exposed topsoil \\
RS4 & Roadside & Ikoku, Diobu & None & Concrete floor \\
YD3 & Fenced Yard & Oyigbo & Car engine service and body refinishing & Exposed topsoil \\
YD4 & Fenced Yard & Oyigbo & Car engine service & Exposed topsoil \\
YD5 & Fenced Yard & Oyigbo & diesel engine and battery services & Exposed topsoil \\
YD6 & Fenced Yard & Oyigbo & Metal scrap dump & Exposed topsoil \\
YD7 & Fenced Yard & Oyigbo & Car engine service & Exposed topsoil \\
RSC & Roadside & RSUST & None & Exposed topsoil \\
YDC & Fenced Yard & RSUST & None & Grass herbs \\
\hline
\end{tabular}

Sampling and Treatment: Surface soil $(0-10 \mathrm{~cm}$ depth) samples were collected from all sites excluding the RS4 (concrete surface) with stainless steel trowel. Deposited dust samples were collected from pavements and concrete floors of adjoining schools and residential homes. Each soil sample comprised 4-6 closely spaced subsamples which were homogenized composite samples of about 1000 $\mathrm{g}$ (wet weight). Typical investigations involving contaminated surface soils in developing countries are based only on the $<2000 \mu \mathrm{m}$ fraction. In order to estimate human exposure risk at the study sites, relevant particles size fractions for the three main exposure pathways (i.e. dermal, ingestion and inhalation) (Environment Agency, 2009; Siciliano et al., 2009) were considered. Following collection, soil samples were air dried, disaggregated and sieved through $2000 \mu \mathrm{m}, 250 \mu \mathrm{m}$, and $75 \mu \mathrm{m}$ meshes. The dust samples were also air dried and sieved through 250 and $75 \mu \mathrm{m}$.

Particle size analysis

The $<2000 \mu \mathrm{m}$ fraction (51 g) of the different samples were quantitatively transferred into screw cap plastic bottles and organic matter was destroyed by adding hydrogen peroxide and sodium hexametaphosphate and the resulting soil analysed by hydrometer method (Rowell, 1994; Keller and Gee, 2006).

Organic matter: About $5.00 \mathrm{~g}$ of the $<2000 \mu \mathrm{m}$ fraction of soils were quantitatively transferred into previously weighed clean porcelain crucibles and heated in a muffle furnace at $400{ }^{\circ} \mathrm{C}$ for 3 hours. The resulting crucibles and their contents were allowed to cool in desiccators and weighed to determine the loss on ignition as a measure of the organic matter (Rowel, 1994; Schumacher, 2002).

Pseudo Total Analysis: Aqua regia digestion $(\mathrm{HCl}$ : $\mathrm{HNO}_{3}$ in the ratio $3: 1 \mathrm{v} / \mathrm{v}$ ) were performed on $0.5 \mathrm{~g}$ subsamples and an aqua regia certified reference material (BCR 143R Sewage sludge amended soil), using hotplate for 2 hours. For each digestion reagent blanks were also prepared. The resulting filtrates were transferred into plastic sample bottles and subsequently analyzed for their $\mathrm{Pb}$ content by Flame (air- $\mathrm{C}_{2} \mathrm{H}_{2}$ ) Atomic Absorption Spectrophotometer (AAS-Buck Scientific).

Experimental Quality Control: The accuracy of the aqua regia digestion method was monitored using BCR 143R (aqua regia certified Sewage sludge amended soil). Excellent results were obtained for total $\mathrm{Pb}(171 \pm 9 \mathrm{mg} / \mathrm{kg})$ determined compared to certificate value $(174 \pm 5)$. All test samples were extracted in triplicate. For the determination of $\mathrm{Pb}$, AAS was calibrated using at least $6 \mathrm{~Pb}$ standards (AccuTrace Reference Standard - AA29N-1) obtained from AccuStandard, Inc, USA. The instrument was re-calibrated after not more than 10 samples. Two quality control standards (high and low range) were analysed after no more than 10 unknown samples. All reported measurements are based on the average of three replicate analyses.

\section{RESULTS AND DISCUSSION}

Particle size analysis and soil organic matter: The contents of sand, silt and clay for test samples are in the range of $2.8-80.0 \%, 18.8-95.1 \%$ and $0.6-$ $2.1 \%$, respectively (Table 2 ). The lowest silt content (YD7) observed in this study is above the contents indicated in the control samples (RSC and YDC) 
(Table 2). The higher content of silt obtained in mechanic workshops compared to the controls is expected since some of the specialized operations at the workshops includes metal grinding and automobile body refinishing. Sample site, YD1; an open air mechanic workshop with metal sheet scrap dumpsite indicated the highest silt content. At YD1 sample site large metal sheet are cut into smaller sizes before their movement to other locations for reuse. The very high silt content at the YD1 may have resulted from the cutting process. The relatively lower contents of sand and clay in the test samples compared to the vegetated control site (Table 1) may be due dilution of their original geochemistry by silts generated during repair works. Samples, RS1, YD1, YD4, YD5 and YD6 indicated higher contents of siltclay compared to the control, RSC and YDC. Excluding RS1 (a site previously used as open dumpsite for domestic waste), all test samples indicated lower soil organic matter than the controls (Table 2). The highest soil organic matter observed at the former domestic waste dumpsite is expected because of food and other human wastes that had interacted with the original surface soil. The lower soil organic matter observed for the other surface soil from mechanic workshops are expected since most waste generated are not organic and biodegradable in nature.

Table 2: Particle size analysis and soil organic matter results

\begin{tabular}{cccccc}
\hline Location & Sand \% & Silt \% & Clay \% & Silt \& Clay \% & $\begin{array}{c}\text { Organic } \\
\text { Matter } \%\end{array}$ \\
\hline RS1 & 50.8 & 46.8 & 2.4 & 49.2 & 15.4 \\
RS2 & 77.4 & 22.0 & 0.6 & 22.6 & 5.8 \\
RS3 & 78.8 & 20.0 & 1.2 & 21.3 & 5.0 \\
YD1 & 2.8 & 95.1 & 2.1 & 97.2 & 3.4 \\
YD2 & 77.4 & 21.4 & 1.2 & 22.6 & 2.6 \\
YD3 & 78.7 & 20.1 & 1.2 & 21.3 & 4.6 \\
YD4 & 55.4 & 42.5 & 2.1 & 44.6 & 3.6 \\
YD5 & 60.0 & 38.0 & 1.8 & 40.0 & 4.0 \\
YD6 & 26.8 & 71.1 & 2.1 & 73.2 & 5.4 \\
YD7 & 80.0 & 18.8 & 1.2 & 20.0 & 5.8 \\
RSC & 91.0 & 6.0 & 3.0 & 9.0 & 8.1 \\
YDC & 77.0 & 16.0 & 7.0 & 23.0 & 6.5 \\
\hline
\end{tabular}

Lead concentration in surface soils: Lead levels measured in the $<2000 \mu \mathrm{m}$ fraction of the surface soil samples were found to range between 40 and 411 $\mathrm{mg} / \mathrm{kg}$, and the range was above the concentrations 24 and $29 \mathrm{mg} / \mathrm{kg}$ found in control samples (YDC and RSC, respectively) (Table 3). The maximum concentration $(411 \mathrm{mg} / \mathrm{kg})$ indicated in this study is above that $(298 \mathrm{mg} / \mathrm{kg})$ reported by Ipeaiyeda et al., (2007) for a newer city, Iwo in Nigeria (Table 4). The maximum concentration $411 \mathrm{mg} / \mathrm{kg}$ observed in this study for the $<2000 \mu \mathrm{m}$ fraction is below, 703, 703 and $2880 \mathrm{mg} / \mathrm{kg}$ reported for similar studies conducted by Iwegbue et al., (2006), Abidemi, (2011), and Adedemi and Abegunde, (2011), respectively (Table 4). The large difference between the maximum observed in this study to that reported for Ibadan, Nigeria by Adedemi and Abegunde, (2011) may be due the fact that Ibadan is a older city than Port Harcourt and the age of the automobile repair shop at Ibadan may be higher. Most of the concentrations are below the soil guideline value of $200 \mathrm{mg} / \mathrm{kg}$ set by the Rivers State Ministry of Environment (RSMenv). Only samples from Ikoku and and Oyibo indicated concentrations of 208 and $411 \mathrm{mg} / \mathrm{kg}$, respectively that are above the local regulatory value. Lead concentrations obtained for < $250 \mu \mathrm{m}$ size fraction were in the range of $62-435$ $\mathrm{mg} / \mathrm{kg}$ (Table 3). The lead concentration range (62 $435 \mathrm{mg} / \mathrm{kg}$ ) observed in this study is consistent with the range $(68.7-396 \mathrm{mg} / \mathrm{kg})$ previously reported by Khan and Kathi, (2014) for surface soil sample investigated at automobile garages in India. Only concentrations of samples from Ikoku (YD2) (241 $\mathrm{mg} / \mathrm{kg}$ ), Oyibo (YD5) (435 mg/kg) and (YD6) (388 $\mathrm{mg} / \mathrm{kg}$ ) were above the local regulatory value $(200$ $\mathrm{mg} / \mathrm{Kg}$ ). The concentrations obtained for the $<75 \mu \mathrm{m}$ fractions were in the range of $61-491 \mathrm{mg} / \mathrm{kg}$ (Table $3)$. For the inhalable fraction $(<75 \mu \mathrm{m})$ about $50 \%$ of the samples indication concentrations that were above the local acceptable limit of $200 \mathrm{mg} / \mathrm{kg}$. The lead concentrations in soil samples were more in the finer fractions. The order of lead loadings in soil samples is; $75 \mu \mathrm{m}>250 \mu \mathrm{m}>2000 \mu \mathrm{m}$.

Lead concentration in deposited dust: The concentrations of lead in the $<250$ fractions were in the range of $138-1819 \mathrm{mg} / \mathrm{kg}$ (Table3). Excluding sample points RS1 and YD7, all other sample points indicated concentration levels above the locally acceptable limit of $200 \mathrm{mg} / \mathrm{kg}$. All the $<250 \mu \mathrm{m}$ dust sample concentrations are two-fold or more those of the $<2000 \mu \mathrm{m}$ soil size fractions. Presently most surface soil contamination studies conducted in developing countries are based on the $<2000 \mu \mathrm{m}$ size 
fraction (Table 4) (e.g. Adedemi and Abegunde, 2011). This observation suggest that published previous studies conducted at automobile repair shops may have under reported risk levels because they were based on the $<2000 \mu \mathrm{m}$ fraction only. The $<75 \mu \mathrm{m}$ fraction concentrations were in the range of $128-1584 \mathrm{mg} / \mathrm{kg}$ (Table 3).

Table 3: $\mathrm{Pb}$ concentrations $(\mathrm{mg} / \mathrm{kg})$ in soils; $<2000 \mu \mathrm{m}, 250 \mu \mathrm{m}$ and $75 \mu \mathrm{m}$, and dust; $<250 \mu \mathrm{m}$ and $75 \mu \mathrm{m}$ fractions

\begin{tabular}{cccccc}
\hline location & $\begin{array}{c}\text { Soil } \\
<75\end{array}$ & $\begin{array}{c}\text { Dust }< \\
75 \mu \mathrm{m}\end{array}$ & $\begin{array}{c}\text { Soil }< \\
250 \mu \mathrm{m}\end{array}$ & $\begin{array}{c}\text { Dust }< \\
250 \mu \mathrm{m}\end{array}$ & $\begin{array}{c}\text { Soil }< \\
2000 \mu \mathrm{m}\end{array}$ \\
& $\mu \mathrm{m}$ & & & & \\
\hline RS1 & 61 & 243 & 62 & 138 & 69 \\
RS2 & 122 & 128 & 64 & 214 & 72 \\
RS3 & 375 & 524 & 140 & 502 & 75 \\
YD1 & 310 & 350 & 181 & 217 & 108 \\
YD2 & 376 & 398 & 241 & 726 & 208 \\
RS4 & 154 & 367 & 124 & 191 & 98 \\
YD3 & 152 & 106 & 133 & 205 & 81 \\
YD4 & 287 & 767 & 107 & 587 & 59 \\
YD5 & 583 & 1584 & 435 & 1819 & 411 \\
YD6 & 491 & 565 & 388 & 420 & 166 \\
YD7 & 126 & 153 & 73 & 188 & 40 \\
RSC & 69 & 77 & 50 & 62 & 30 \\
YDC & 54 & 48 & 36 & 45 & 24 \\
\hline
\end{tabular}

The concentrations observed for the re-suspendable size fraction were also higher than those for the < $2000 \mu \mathrm{m}$ fraction. Excluding sample points YD2 and
YD3 all other sample points indicated concentrations that were at least two times higher than those for the $<2000 \mu \mathrm{m}$. The finer fractions are usually expected to have higher loadings of contaminants, but results obtained in this study indicate some exceptions; samples obtained from RS2, YD2, YD3 and YD5 indicated higher $\mathrm{Pb}$ loading for the $<250 \mu \mathrm{m}$ than the $<75 \mu \mathrm{m}$ size fraction. The elevated lead concentrations observed for the more coarse size fraction samples (RS2, YD2 and YD3) may be due the fact that automobile body refinishing jobs were taking place alongside the car engine servicing. Since one of the activities at automobile body workshops involve scrapping of old automobile body surfaces the generated paint dust and metal fillings may have contributed the large lead loadings.

Soil ingestion exposure assessment at automobile mechanic yards: In developed countries, currently human health risk assessment studies from soil are based on ingestible $(<250 \mu \mathrm{m})$ and fine particles of soil $(<100 \mu \mathrm{m})$ fractions (e.g. Boisa et al., 2013; Boisa et al., 2014). Using the $<250 \mu \mathrm{m}$ size fraction $\mathrm{Pb}$ concentrations in surface soil and deposited dust, it was possible to estimate the potential the potential human exposure risk associated with the ingestion of any of the matrices. The method used here is based on calculating the $\mathrm{Pb}$ daily intake $(\mathrm{Pb} \mathrm{DI})$ from incidental ingestion.

Table 4: Soil and dust $\mathrm{Pb}$ concentrations in automobile service garages

\begin{tabular}{|c|c|c|c|}
\hline $\begin{array}{l}\mathrm{Pb} \text { Conc. } \\
\text { Range } \\
(\mathrm{mg} / \mathrm{kg})\end{array}$ & Study Location & $\begin{array}{l}\text { Particle size } \\
(\mu \mathrm{m})\end{array}$ & Authors \\
\hline $40.0-411$ & Port Harcourt, Nigeria & $<2000$ & This study \\
\hline $62.0-435$ & Port Harcourt, Nigeria & $<250$ & This Study \\
\hline $61.0-583$ & Port Harcourt, Nigeria & $<75$ & This study \\
\hline $246-703 *$ & Port Harcourt, Nigeria & Not indicated & Iwegbue et al., 2006 \\
\hline $68.7-396$ & Puducherry, India & $<250$ & Khan and Kathi, 2014 \\
\hline $106-298$ & Iwo, Nigeria & Not indicated & Ipeaiyeda et al., 2007 \\
\hline $11.7=2880$ & Ibadan, Nigeria & $<2000$ & Adedemi and Abegunde, 2011 \\
\hline $16.0-703$ & Osogbo, Nigeria & Not indicated & Abidemi, 2011 \\
\hline
\end{tabular}

*- auto-mechanic waste dump sites

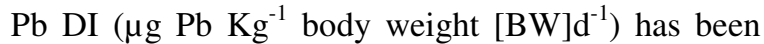
calculated for children (2-6 years) that may later occupy these emerging brownfields and pupils presently studying in schools sited within or around mechanic garages based on their pica habits as:

$$
P b . D I=\frac{(E C \times S I R \times E D)}{B W}
$$

Where; $\mathrm{EC}$ is aqua regia $\mathrm{Pb}$ concentration, $\mu \mathrm{g} / \mathrm{g}$; SIR is soil ingestion rate, $\mathrm{mg} / \mathrm{d}$ (given as $100 \mathrm{mg} / \mathrm{d}$ for the age group of interest) (US EPA, 2011);ED is exposure duration, to be 0.5 as exposure could be 12 hours per day, 365 days a year; BW is body weight, $17.8 \mathrm{~kg}$ (US EPA, 2011) for the age group of interest.

The automobile artisans workshops investigated in this study are adjourning either primary or nursery school. Some of the shops had additional businesses like food canteens and in few cases wives of artisans and their below school age children stay at the shops to assist. The soils and deposited dust sampled in this study are in contact with the population. However, because of the vulnerability of children this study sought to quantify the exposure to children in the age range of 2-6 years. Exposure estimate were 
calculated for topsoil and deposited dust samples using the concentration data (Table 3). The data for test samples (Table 5) suggest the daily intake is in the ranges of $0.17-1.22 \mu \mathrm{g} \mathrm{Pb} \mathrm{Kg}{ }^{-1}$ body weight $[\mathrm{BW}] \mathrm{d}^{-1}$ and $0.39-5.11 \mu \mathrm{g} \mathrm{Pb} \mathrm{Kg}^{-1} \mathrm{BWd}^{-1}$ for soil and deposited dust, respectively. All soil samples indicated lower Pb DI values than the TDI (1.9 $\mu \mathrm{g} \mathrm{Pb}$ $\mathrm{Kg}^{-1}$ body weight $[\mathrm{BW}] \mathrm{d}^{-1}$ ), however, they are above the $\mathrm{Pb} \mathrm{DI}$ values for the controls $(0.10$ and $0.14 \mu \mathrm{g}$ $\left.\mathrm{Pb} \mathrm{Kg}{ }^{-1} \mathrm{BWd}^{-1}\right)$. Two $\mathrm{Pb}$ DI values, 2.04 and $5.11 \mu \mathrm{g}$ $\mathrm{Pb} \mathrm{Kg} \mathrm{KWd}^{-1}$ obtained for YD2 and YD5, respectively, are higher than the recommended TDI for $\mathrm{Pb}\left(1.9 \mu \mathrm{g} \mathrm{Pb} \mathrm{Kg}{ }^{-1} \mathrm{BWd}^{-1}\right)$. The $\mathrm{YD} 2$ site is employed for both car engine servicing and automobile body refinishing works (Table 1). The YD5 site is engaged in diesel engine truck and battery services (Table 1). The elevated $\mathrm{Pb} \mathrm{Di}$ obtained for YD5 yard may be due the fact that the high pressure-resistant lubricants employed for diesel engines contains lead Naphthenate (Clausen and Rastogi, 1977). Our data highlights that a possibility of harm exist via exposure to the deposited dusts. Implications for occupiers of residence sited on Brownfields resulting from mechanic activities

Table 5: Lead daily intake (Pb DI) orally ingested from topsoil and deposited dust, tolerable daily intake (TDIoral) based on sample aqua regia concentration. Number in bold indicate $\mathrm{a} \mathrm{Pb}$ intake greater than the TDI

\begin{tabular}{cccc}
\hline Location & \multicolumn{2}{c}{$\mathrm{Pb} \mathrm{DI}\left(\mu \mathrm{gkg}^{-1} \mathrm{BWd}^{-1}\right)$} & $\begin{array}{c}\text { TDI }(\mu \mathrm{gkg}- \\
\left.\mathrm{BWd}^{-1}\right)\end{array}$ \\
\hline RS1 & soil & Dust & $1.9^{*}$ \\
$\mathrm{RS} 2$ & 0.17 & 0.39 & \\
RS3 & 0.39 & 0.60 & \\
YD1 & 0.51 & 1.40 & \\
YD2 & 0.68 & 0.61 & \\
RS4 & 0.35 & 2.04 & \\
YD3 & 0.37 & 0.54 & \\
YD4 & 0.30 & 1.65 & \\
YD5 & 1.22 & 5.11 & \\
YD6 & 1.09 & 1.17 & \\
YD7 & 0.20 & 0.52 & \\
RSC & 0.14 & 0.17 & \\
YDC & 0.10 & 0.13 & \\
\hline \multicolumn{4}{c}{ * JEFCA $(2012)$}
\end{tabular}

Existing environmental risk assessment allows for the comparison of soil aqua regia extractable total of potentially harmful elements with environmental quality guidelines. This study has shown the possibility of link between $\mathrm{Pb}$ concentrations in surface soils and deposited dusts within automobile mechanic yards. Whilst direct soil ingested can be monitored in children, the deposition of suspended surface dust on children hands and subsequent ingestion might be difficult to monitor. All dust samples indicated higher $\mathrm{Pb} \mathrm{DI}$ than the soil samples. Permanent residency at such land areas may expose inhabitants to unacceptable $\mathrm{Pb}$ intake. In order to minimize $\mathrm{Pb}$ intake risk management strategies such as soil encasement, re-vegetation and soil replacement will be required. Whilst attempts are made to have better understanding of sources of $\mathrm{Pb}$ at mechanic yards and effect contaminants management, it is essential that the danger of leasing landed properties for mechanic services be highlighted.

Conclusion: This study investigated the levels of $\mathrm{Pb}$ in surface soils and dusts obtained from eleven (11) land areas previously used for automobile mechanic and other associated services and two (2) control sites. Our data indicated elevated soil- $\mathrm{Pb}$ levels for the automobile service sites. Whilst published similar studies in developing countries were principally based only on the $<2000 \mu \mathrm{m}$ particle size fraction of soils, this study in addition of the classical $<2000$ $\mu \mathrm{m}$ size fraction of soil also considered two other size fractions $(<250$ and $<75 \mu \mathrm{m})$ and dust matrix.

The higher $\mathrm{Pb}$ levels observed in the dusts samples highlights the relevance of this matrix. Risk assessment for accidental ingestion of soil and dust based on the $<250 \mu \mathrm{m}$ fraction indicated more daily intake doses of $\mathrm{Pb}$ from dust than soil. Two sites;(1). a site used for diesel engine and battery services, and (2) a site used for car engine service and automobile body refinishing work indicated daily $\mathrm{Pb}$ intake doses that exceeded current tolerable daily intake value. The utilization of dust data for the estimation of children exposure doses may however be overprotective of children's health.

Most of the sites investigated were engaged in multiple automobile mechanic and welding services; therefore it was difficult to account for the specific activities responsible for high $\mathrm{Pb}$ loadings. There is therefore need to conduct a source apportionment studies of potentially harmful elements at automobile yards and sites. Data from such studies may assist in identifying services associated with higher lead loadings.

Acknowledgement: We wish to thank Dr. C.C. Obunwo, Mrs Chukwudi Chinyere, Rita Paul Akpan and Joseph Moses for their assistance in various capacities during the course of this research.

\section{REFERENCES}

Abidemi O.O. (2011) Levels of Pb, Fe, Cd and Co in soils of automobile workshop in Osun State, Nigeria. J. Appl. Sci. Environ. Manage 15: 277282. 
Adela Y., Ambelu A., and Tessema D.A. (2012) Occupational lead exposure among automotive garage workers- a case study for Jimma town, Ethiopia. Journal of Occupational Medicine and Toxicology 7:15

Adelekan B.A., and Abegunde K.D. (2011) Heavy metals contamination of soil and ground water at automobile mechanic village Ibadan, Nigeria. Int J. Phys. Sci. 6:1045-1058.

Boisa N., Bird G., Brewer P.A., Dean J.R., Entwistle J.A., Kemp S.J. and Macklin M.G. (2013) potentially harmful elements (PHEs) in scalp hair, soil and metallurgical wastes in Mitrovica, Kosovo: the role of oral bio accessibility and mineralogy in human PHE exposure. Environment International 60: 56-70

Boisa N., Elom N., Dean J.R., Deary M.E., Bird G., and Entwistle J.A. (2014) Development and application of an inhalation bioaccessibility method (IBM) for lead in the PM10 size fraction of soil. Environment International 70: 132-142.

Clausen J and Rastogi S.C. (1977) Heavy metalpollution among autoworkers. 1. Lead. British Journal of Industrial Medicine 34: 208215 .

\section{EMASC-001.}

http://bcodata.whoi.edu/LaurentianGreatLakes_ Chemistry/bs116.pdf.

Enander R.T., Cohen H.J., Gunte D.M., Brown L.C., Desmaris A.M.C., and Missaghian R. (2004) Lead and methylene chloride exposure among automotive repair technicians. Journal of Occupational and Environmental Hygiene 1: 19125.

Environment Agency. Human health toxicological assessment of contaminants in soil. Science Report-SC050021/SR2 UK: Environment Agency 2009.

Eum K.D., Wang F.T., Schwartz J., Harsh C.P., Kesley K., Wright R.O., Spiro A., Sparrow D., Hu H., Weisskopt M.G., (2013) Modifying roles of glutathione s-transferase polymorphism on the association between cumulative lead exposure and cognitive function. Neurotoxicology 39: 6571.

Hong S-B., Im M-H., Kim J-W., Park E-J., Shin MS., Kim B-N., Yoo H-J., Cho I-H., Bhan S-Y., Hong Y-C., and Cho S-C (2015) Environmental lead exposure and attentiondeficient/hyperactivity disorder symptom domains in a community sample of South Korean school-age children. Environmental Health Perspectives 123: 271-276.

Ipeaiyeda A.R., Dawodu M., and Akande Y., (2002) Heavy metals contamination of top soil and dispersion in the vicinities of reclaimed autorepair workshops in Iwo, Nigeria. Research Journal of Applied Sciences 2: 1106-1115.

Iwegbue C.M.A., Isirimah N.O., Igwe C., and Williams E.S. (2006) Characteristic levels of heavy metals in soil profiles of automobile mechanic waste dumps in Nigeria. Environmentalist 26: 123-128.

JECFA (Joint FAO/WHO Expert Committee on Food Additives) summary report of the seventy-sixth meeting of JECFA, Geneva; 2012 pp.16 95-14 June).

Keller J.M., and Gee G.W. (2006) Comparison of American Society of Testing Materials and Soil Science Society of America hydrometer methods for particle-size analysis. Soil Science society of America Journal 70: 1094-1100.

Khan A.B., and Kathi S., (2014) Evaluation of heavy metal and total petroleum hydrocarbon contamination of roadside surface soil. international Journal of Environmental Science and Technology 11: 2259-2270.

Laidlaw M.A.S., Zahran S., Pingitore N., Clague J., Devlin G., and Taylor M.P. (2014) Identification of lead sources in residential environments: Sydney, Australia. Environmental Pollution 184: 238-246.

Mackay A.K., Taylor M.P., Munksgaard N.C., Hudson-Edwards K.A., and Burn=Nunes L. (2013) Identification of environmental lead sources and pathways in a mining and smelting town: Mount Isa, Australia. Environmental Pollution 18:, 204-211.

Oktem F., Arstan M.K., Dundar B., Gultepe M., and Erqurhan I.I. (2004) Renal effects and erythrocyte oxidative stress in long-term lowlevel lead-exposed adolescent workers in auto repair workshops. Arch Toxicol 78: 681-687.

Pena-Icart, M., Villanueva Tagle, M.E., Hernández, C.A., Hernández, J.R., Behar, M., Pomares Alfonso, M.S. (2011) Comparative Study of 
Digestion Methods EPA 3050B (HNO3-H2O2$\mathrm{HCl}$ ) and ISO 11466.3 (aqua regia) for $\mathrm{Cu}, \mathrm{Ni}$ and $\mathrm{Pb}$ Contamination Assessment in Marine Sediments, Marine Environmental Research. 72: 60-66.

Pottier G., Viau M., Ricoul M., Shim G., Bellamy N., Cuceu C., Hampel W.M., and Sabatier L. (2013) Lead exposure induces Telomere instability in human cells. Plos One 8: e67501.

Schumacher B.A. (2002) Methods for the determination of total organic carbon (TOC) in soils and sediments

Shastri N.M. and Plant H. (2011) Genotoxic profile of motor garage workers. American Journal of Infectious Diseases 7: 55-60.

Siciliano S.D., James K., Zhang G., Schafer A.N., and Peak J.D. (2009) Adhesion and enrichment of metals in human hands from contaminated soil at an Arctic urban Brownfield Environmental Science \& Technology 43: 63856390.

Taukuila J., Mbuyi F., Kambamba M., Lantin A.C., Lison D., and Hoet P. (2010) Blood lead levels in Kinshasa population: a pilot study. Arch Public Health 68: 30-41.
Toulmin C., (2009) Securing land and property rights in sub-Saharan Africa: The role of the local institutions. Land Use Policy 26: 10-19.

US Environmental protection Agency. Exposure factor handbook: 2011 edition. EPA/600/R09/052 F. Washington DC: US. Environmental Protection Agency; 2011

Weuve J., Press D.Z., Grodstein F., Wright R.O. Hu H., and Weisskopf M.G. (2013) Cumulative exposure to lead and cognition in persons with Parkinson's disease. Movement Disorders 28: 176-182.

Zahran S., Laidlaw M.A.S., McElmurry S.P., Filippelli G.M., and Taylor M. (2013) Resuspended soil lead and children blood lead levels in Detroit, Michigan. Environmental Science \& Technology 47: 2839-2845. 